Kaundun, S. S. and S. Matsumoto (2002): Heterologous nuclear and chloroplast microsatellite amplification and variation in tea, Camellia sinensis. Genome $\mathbf{4 5}$ : 1041-1048.

LAROCHE, J. and J. D. DuRAND (2004): Genetic structure of fragmented populations of a threatened endemic percid of the Rhone river: Zingel asper. Heredity 92(4): 329-334.

Mac Donagh, P. and L. Rivero (2005): ¿Es posible el uso sustentable de la selva Misionera?, pp. 210-217. In: La situación Ambiental Argentina, edited by A. BRown, U. Martinez Ortiz, M. ACERBI and J. CorcuerA, Fundación Vida Silvestre Argentina, Buenos Aires.

Marchelli, P. and L. Gallo (2006): Multiple ce-age refugia in a southern beech of South America as evidenced by chloroplast DNA markers. Cons Genet 7: 591-603.

Marchelli, P., C. Baier, C. Mengel, B. Ziegenhagen and L. A. GALLO (2010): Biogeographic history of the threatened species Araucaria araucana (Molina) K. Koch and implications for conservation: A case study with organelle DNA markers. Conserv Genet 11: 951-963.

NEI, M. (1987): Molecular evolutionary genetics. Columbia University Press, New York. 512p.

Pastorino, M. J., P. Marchelli, M. Milleron, C. Solian and L. A. GALlo (2009): The effefct of different glaciation patterns over the current genetic structure of the southern beech Nothofagus antartica. Genetica 136(1): 79-88.

Peakall, R., S. Gilmore, W. Keys, M. Morgante and A. RAFALSKI (1998): Cross-Species Amplification of Soybean (Glycine max) Simple Sequence Repeats (SSRs) Within the Genus and Other Legume Genera: Implications for the Transferability of SSRs in Plants. Mol Biol Evol 15(10): 1275-1287.
Peakall, R. and P. E. Smouse (2006): Genalex 6: genetic analysis in Excel. Population genetic software for teaching and research. Mol Ecol Not 6(1): 288-295.

Powell, W., M. Morgante, R. McDevitt, G. G Vendramin and J. A. RAFALSKI (1995): Polymorphic simple sequence repeats regions in chloroplast genomes: Applications to the population genetics of pines. Proc Natl Acad Sci USA 92(17): 7759-7763.

Provan, J., W. Powell and P. M. Hollingsworth (2001): Chloroplast microsatellites: new tools for studies in plant ecology and evolution. Trends Ecol Evol 16(3): $142-147$.

Ryman, $\mathrm{N}$ and O. LeIMAR (2009): $\mathrm{G}_{\mathrm{ST}}$ is still a useful measure of genetic differentiation - a comment on Jost's D. Mol Ecol 18: 2084-2087.

SAMBrook, J., E. F. Fritsch and T. MANiatis (1989): Molecular Cloning: A Laboratory Manual. Cold Spring Harbor Laboratory Press.

SChuster, I. and C. D. CRUZ (2004): Estatística genómica aplicada a populações derivadas de cruzamentos controlados. Viçosa MG: Editora UFV 568p.

Steiner, J. J., C. J. Pocklemba, R. G. FJellstrom and L. F. Elliot (1995): A rapid one tube genomic DNA extraction process for PCR and RAPD analyses. Nucleic Acid Res 23(13): 2569-2570.

WEISING, K. and R. C. GARDNER (1999): A set of conserved PCR primers for the analysis of simple sequence repeat polymorphisms in chloroplast genomes of dicotyledonous angiosperms. Genome 42(1): 9-19.

YeH, F. C. and T. J. B. BoYLe (1997): Population genetic analysis of co-dominant and dominant markers and quantitative traits. Belg J Bot 129: 157.

ZANe, L., L. BARgelloni and T. PATARNello (2002): Strategies for microsatellite isolation: a review. Mol Ecol 11: $1-16$.

\title{
Heritability of Yield and Secondary Traits in two populations of Para Rubber Tree (Hevea brasiliensis)
}

\author{
By C. NARAYANAN*) and KaVitha K. MYdin
}

(Received $4^{\text {th }}$ May 2010)

\begin{abstract}
Heritability and interactions of yield and growth traits were assessed in Hevea brasiliensis using full-sib progenies and clonal populations. Using parent-offspring regression, annual mean rubber yield (ARY) and summer yield (SY) showed moderate to high heritability (ARY, $h^{2}=34-56 \%$; SY, $h^{2}=36-52 \%$ ). Among the yield components, girth exhibited low to moderate heritability ( $h^{2}=17-36 \%$ ) while branching height showed low heri-

\footnotetext{
*) Corresponding author: C. NARAYANAN. Crop Improvement Group, Botany Division, Rubber Research Institute of India, India. Ph: +91-481-2353311, Fax: +91-481-2353327. E-Mail cnarayanan@rubberboard.org.in
}

tability $\left(h^{2}=18 \%\right)$. Using forty clonal genotypes, annual mean rubber yield $\left(H^{2}=48 \%\right)$, rubber yield during peak period $\left(H^{2}=47 \%\right)$ and rubber yield during stress (or summer yield) $\left(H^{2}=44 \%\right)$ showed high estimates of heritability. Among the other yield components, except volume of latex during stress period $\left(H^{2}=40 \%\right)$, remaining yield components showed moderate estimates for heritability $\left(H^{2}=29-37 \%\right)$. Dry rubber content (DRC) based on annual mean showed very high heritability $\left(H^{2}=68 \%\right)$, followed by DRC during stress $\left(H^{2}=51 \%\right)$ and peak $\left(H^{2}=50 \%\right)$ periods. Latex flow rate based on annual mean and peak period data showed high heritability $\left(H^{2}=51 \%\right)$ followed by latex flow rate during stress period $\left(H^{2}=42 \%\right)$. Plugging indices of annual and 
stress period showed high heritability $\left(H^{2}=43 \%\right)$ than that of peak period $\left(H^{2}=25 \%\right)$. Regarding growth traits, girth showed high heritability $\left(H^{2}=50 \%\right)$ than girth increment $\left(H^{2}=32 \%\right)$. While bark thickness showed high heritability $\left(H^{2}=40 \%\right)$ length of tapping panel showed moderate heritability $\left(H^{2}=27 \%\right)$. Total chlorophyll content exhibited moderate heritability $\left(H^{2}=22 \%\right)$; chlorophyll pigment ratio showed low heritability $\left(H^{2}=5 \%\right)$. Based on parent-offspring analysis, annual mean rubber yield exhibited high genetic correlation with summer yield and girth. Annual mean rubber yield and summer yield were negatively correlated with branching height. Regarding phenotypic correlations among the forty clonal genotypes, annual mean rubber yield exhibited high correlation with latex volume, latex flow rate, DRC, girth and bark thickness. However, annual mean rubber yield was negatively correlated with yield depression under stress and plugging index. Rubber yield, volume and rate of flow of latex over the three periods, yield depression under stress, girth increment, annual mean plugging index and plugging index under stress showed high estimates of genetic advance. The high estimates of heritability for yield and its components coupled with their high genetic gain indicated that considerable improvement can be achieved for these traits through selection. Estimates for indirect selection efficiency were not optimal for indirect selection for yield using girth and summer yield.

Key words: Hevea brasiliensis, full-sibs, clonal population, latex yield, dry rubber content, girth, branching height, genotypic coefficient of variation, phenotypic coefficient of variation, parent-offspring regression, heritability, genetic correlation, phenotypic correlation, genetic gain.

\section{Introduction}

Hevea brasiliensis (Willd. ex A. Juss.) Müll. Arg. (family, Euphorbiaceae; diploid, $2 \mathrm{n}=36$ ), the Para rubber tree, is monoecious and entomophilic with a strong tendency to out-breed. Laticifer cells located in the bark tissue of the tree yield latex (essentially cytoplasmic fluid), which is the major source of natural rubber in the entire plant kingdom. Through controlled manual incision and subsequent removal of bark tissues, latex is systematically collected and used, predominantly by various rubber-based industries. The process of removal of bark tissue and collection of latex is referred to as 'tapping'. Although the Para rubber tree is a forest tree species, it has been effectively domesticated within a short period of less than five decades since it was introduced into Southeast Asia in 1876.

Latex yield in $H$. brasiliensis and other traits including vigour, resistance to abiotic and biotic factors, like many economic traits in forest trees, are quantitative or polygenically controlled. Even though latex yield is governed by the genetic potential of planting material, the expression of the genetic potential could be influenced by (i) other inherent factors of the genotype like vigour, bark thickness, resistance to wind damage and major diseases, (ii) environmental factors like soil, rainfall etc. and (iii) agromanagment practices e.g. tapping systems, chemical stimulation, planting density, fertilizer inputs etc (TAN, 1987). Nevertheless, in most of the $H$. brasiliensis breeding programmes, latex yield has been the primary target trait for genetic improvement.
Selection and breeding for yield and other economic traits for realizing genetic gains require accurate information on heritability or inheritance pattern of these traits. Heritability, which is an estimate of the fraction of phenotypic variance that can be realized by selection, is estimated using variance ratio or parent-offspring regression. Existing reports on heritability estimates in $H$. brasiliensis rubber are based on variance analysis. Parent-offspring regression has been suggested as an alternative and robust statistical procedure for estimating heritability and assessing genetic correlation (GILBERT, 1973; SimMONDS, 1979; FALCONER and MACKAY, 1996). In the present study, an attempt was made to estimate heritability and correlations of various economic traits in $H$. brasiliensis using two different populations adopting the above biometrical methods.

\section{Materials and Methods}

\section{Experimental material}

Two different populations were utilized for assessing genetic parameters. The first population consisted of 11 separate families of full-sib progenies (derived from a hybridization programme involving 14 parental clones in various combinations) and their parent clones, planted in 1993 in a small scale trial at Central Experimental Station, Chethackal (Pathanamthitta Dt., Kerala), adopting a replicated simple lattice design ( $5 \times 5$ design, four replicates, seven trees per replication). The trees were opened for tapping in 2001. Annual mean rubber yield (ARY, coagulated latex weighed in grams per tree per tap; $\mathrm{gt}^{-1} \mathrm{t}^{-1}$ ) based on annual mean of twelve month recordings (Jan-Dec) was recorded separately in all the trees following cup coagulation method. In addition to the above, yield during stress period (Feb-May), namely the summer yield (SY), was also computed based on mean of the yield recordings during the above period. Growth traits viz. girth (at $150 \mathrm{~cm}$ ) and branching height (clear bole height) were also assessed. All the above parameters were measured in 2008 when trees were 17-year-old.

The second population consisted of forty clones originating from India, Indonesia, Malaysia and Sri Lanka, planted in a randomized block design (three replications, five trees per plot) at the same Central Experimental Station at Chethackal. Data was collected on rubber yield and related physiological, morphological and structural attributes, during the fourth year of tapping. Yield and related physiological parameters included dry rubber yield, dry rubber content (D.R.C.), rate of latex flow and plugging index (MILFORD et al., 1969) which were recorded at monthly intervals for one year. Data were also collected on the above traits during stress period (Feb-May) and peak period (Sept-Dec). The summer depression (SD\%; decline of yield during summer) in rubber yield during stress period (Feb-May) was computed as follows equation [1]:

$$
\text { Summer Depression }(S D \%)=\frac{\text { Annual Mean Rubber Yield-Summer Yield }}{\text { Annual Mean Rubber Yield }} * 100
$$

In addition to the above, leaf chlorophyll content and chlorophyll a:b ratio (ARNON, 1949) were also recorded 
Table 1. - Narrow sense heritability of yield and growth traits in Hevea brasiliensis based on parent-offspring regression $(b)$.

\begin{tabular}{lccccc}
\hline $\begin{array}{c}\text { Parent progeny } \\
\text { relationship }\end{array}$ & $\begin{array}{c}\text { Heritability } \\
\text { equations }\end{array}$ & $\begin{array}{c}\mathrm{ARY} \\
\left(\mathrm{gt}^{-1} \mathrm{t}^{-1}\right)\end{array}$ & $\begin{array}{c}\mathrm{SY} \\
\left(\mathrm{gt}^{-1} \mathrm{t}^{-1}\right)\end{array}$ & $\begin{array}{c}\mathrm{G} \\
(\mathrm{cm})\end{array}$ & $\begin{array}{c}\mathrm{BH} \\
(\mathrm{m})\end{array}$ \\
\hline $\begin{array}{l}\text { Offspring - } \\
\text { female parent }\end{array}$ & $h^{2}=2 b$ & -0.18 & -0.22 & -0.14 & -0.28 \\
\hline $\begin{array}{l}\text { Offspring - } \\
\text { male parent }\end{array}$ & $h^{2}=2 b$ & 0.56 & 0.52 & 0.36 & 0.18 \\
\hline $\begin{array}{l}\text { Offspring- } \\
\text { midparent mean }\end{array}$ & $h^{2}=b$ & 0.34 & 0.36 & 0.17 & -0.11 \\
\hline
\end{tabular}

AMY - Annual mean yield; SY - Summer yield; G - Girth; BH -

Branching height.

along with girth, length of tapping panel and bark thickness. The above data were collected during fourth year of tapping.

\section{Narrow sense heritability and genetic correlation in full-sib population}

Based on data from the full-sibs and their parent clones, narrow sense heritability of yield and growth traits was estimated (Table 1) based on parent-offspring regression (ZOBEL and TALBERT, 1984; FALCONER and MACKAY, 1996). The regression (bop) is expressed as equation [2]:

$$
b_{o p}=\frac{\operatorname{cov}_{o p}}{\sigma_{p}^{2}}
$$

(where $b_{o p}$ is the regression of offspring on parent, $C O V_{o p}$ is the covariance of offspring on parents and $\sigma_{p}^{2}$ is the variance of parents).

For regression analysis, the mean values of parents and that of progenies were subjected to regression in which the sloping line indicates the linear regression of offspring on mid-parent. The slope of the line $(b)$ provides a direct estimation of narrow sense heritability $\left(h^{2}\right)$ for the particular trait. The regression equation is as equation [3]:

$$
y=b x+e
$$

(where $y=$ average of progeny values, $b=$ regression coefficient (slope of line), $x=$ mid-parent value, $e=$ error (lack of fit of values to the line)

Heritability estimates were derived with the data grouped in the following ways (STEINHOFF and HoFF, 1971): (1) Progeny on female parents, (2) Progeny on male parents and (3) Progeny on midparent. When analysis is performed using values of progenies and one of the parents (either female or male parent) the regression coefficient $b$ equals half the narrow sense heritability. However, when progeny values were regressed on the midparent values, the regression coefficient $(b)$ equals narrow-sense heritability (ZOBEL and TALBERT, 1984).

Genetic correlation of yield and growth traits was computed based on the offspring-parent relationship (FALCONER and MACKAY, 1996). For estimation of genetic correlation between two traits, "cross-variances" were obtained from the product of the value of ' $\mathrm{X}$ ' in parents and the value of ' $\mathrm{Y}$ ' in offspring. The covariance of off- spring and parents for each trait, which provide estimation on genetic correlation $\left(r_{A}\right)$, was computed using $C O V_{X Y}$ ('cross-variance') and $C O V_{X X}$ and $C O V_{Y Y}$, the offspring-parent covariances of each trait separately, as equation [4]:

$$
r_{A}=\frac{\operatorname{cov}_{x y}}{\sqrt{\operatorname{cov}_{x x} \operatorname{cov} y y}}
$$

In general, cross-variance may be calculated from ' $X$ ' in parents and ' $Y$ ' in offspring or from ' $Y$ ' in parents and ' $X$ ' in offspring. In the present study since both the values were available, the arithmetic mean was used.

\section{Broad sense heritability, phenotypic correlation and genetic gain in clonal population}

For estimation of broad sense heritability $\left(H^{2}\right)$, data from the forty clones in the second trial was subjected to separate analysis of variance (ANOVA) for each trait using SPSS (version 10.0.1) statistical analysis software by adopting the model as equation [5]:

$$
Y_{i j}=\mu+g_{i}+r_{j}+e_{i j}
$$

(where $Y_{i j}$ is the measurement of a trait on the $i^{\text {th }}$ genotype (clone) in the $j^{\text {th }}$ replication, $\mu$ is the overall mean of the population, $g_{i}$ is the effect of the $i^{\text {th }}$ genotype $(i=1,2, \ldots g=40), r_{j}$ is the effect of the $j^{\text {th }}$ replication $(j=1,2 \ldots=3)$ and $e_{i j}$ is the experimental error associated with the $i^{\text {th }}$ genotype in the $j^{\text {th }}$ replication).

The genotypic, phenotypic and environmental components of variance were estimated by equating the expected mean squares to the corresponding mean squares of the ANOVA (Table 2) as equations [6] and [7] (KEMPTHORNE, 1957):

$$
\begin{aligned}
& \sigma_{g}^{2}=\frac{\left(\sigma_{e}^{2}-\mathrm{r} \cdot \sigma_{g}^{2}\right)-\sigma_{e}^{2}}{\mathrm{r}} \\
& \sigma_{p}^{2}=\sigma_{g}^{2}+\sigma_{e}^{2}
\end{aligned}
$$

(where $\sigma_{g}^{2}$ is the genetic variance among genotypes (clones), $\sigma_{e}^{2}$ is the environmental variance, $\sigma_{p}^{2}$ is the phenotypic variance and $r$ is the number of replications).

The genotypic co-efficient of variation (G.C.V.), phenotypic co-efficient of variation (P.C.V.) and broad sense heritability $\left(H^{2}\right)$ were calculated as equations [8], [9] and [10] (BURTON and DE VANE, 1953): 
Table 2. - Degrees of freedom (d.f.) and expected mean squares (EMS) for estimating components of variance.

\begin{tabular}{lll}
\hline Source of variation & d.f. & EMS \\
\hline Replications (r) & $\mathrm{r}-1$ & \\
Genotypes (g) & $\mathrm{g}-1$ & $\sigma_{e}^{2}+r \sigma_{g}^{2}$ \\
Error & $(\mathrm{r}-1)(\mathrm{g}-1)$ & $\sigma_{e}^{2}$ \\
\hline
\end{tabular}

$\mathrm{r}$ - number of replications; $\mathrm{g}$ - number of clones (genotypes); $\sigma_{e}^{2}$ - environmental variance; $\sigma_{g}^{2}-$ genotypic variance.

$$
\begin{aligned}
& \text { G.C.V.\% }=\frac{\sqrt{\sigma_{g}^{2}}}{\bar{X}} \times 100 \\
& \text { P.C.V.\% }=\frac{\sqrt{\sigma_{p}^{2}}}{\bar{X}} \times 100 \\
& H^{2}=\frac{\sigma_{g}^{2}}{\sigma_{p}^{2}}
\end{aligned}
$$

(where $\bar{X}$ is the general mean for each trait)

In order to understand the association between yield and its related components, phenotypic $\left(r_{p}\right)$ correlations were worked out (KEMPTHORNE, 1957; FALCONER and MACKAY, 1996) as equation [11]:

$$
r_{p_{(x y)}}=\frac{c o v_{p_{x y}}}{\sigma_{p_{x}} \sigma_{p_{y}}}
$$

(where $C O V_{p_{x y}}$ is the estimate of phenotypic covariance between two variables $x$ and $y$, and $\sigma_{p_{x}}$ and $\sigma_{p_{y}}$ are the estimates of genotypic standard deviations of $x$ and $y$, respectively).

The genetic gain (genetic advance) or direct response to selection $(R)$ was calculated as equation [12] (FALCONER and MACKAY, 1996) and expressed as percentage of mean (R\%) as equation [13] (BURTON and DE VANE, 1953):

$$
\begin{aligned}
& R=i \cdot H^{2} \cdot \sigma_{p} \\
& R \%=\frac{R}{\bar{X}} \times 100
\end{aligned}
$$

(where $i$ is the intensity of selection, $H^{2}$ is the broad sense heritability and $\sigma_{p}$ is the phenotypic standard deviation)

\section{Indirect selection using component traits}

If two traits, $x$ and $y$, are genetically correlated, and if trait $\mathrm{x}$ is time consuming and difficult to measure with precision, it may be possible to make selection on trait $y$, and achieve correlated response in trait $x$. The efficiency of such indirect selection may be expressed as the ratio of the expected responses (FALCONER and MACKAY, 1996). Based on heritability and genetic correlation estimated using full-sib population, indirect selection efficiency for the yield and yield components was examined using equation [14]:

$$
\frac{C R_{x}}{R_{x}}=r_{g} \frac{i_{y} H_{y}}{i_{x} H_{x}}
$$

(where $C R_{x}$ is the correlated response of trait $x$ due to selection applied to the secondary trait $y, R_{x}$ is the direct response of selection for the primary trait $x, r_{g}$ is the genotypic correlation coefficient between traits $x$ and $y$, $H_{x}$ and $H_{y}$ are the square roots of heritability estimates for the traits $x$ and $y$, respectively).

Selection efficiency ratio is effective if $r_{g} \cdot H_{y}$ (genetic correlation $\mathrm{x}$ heritability of the secondary trait) is greater than the heritability of the primary trait $\left(H_{x}\right)$. Thus, indirect selection would be advantageous over direct selection when the secondary trait possesses higher estimates for heritability and genetic correlation.

\section{Results and Discussion}

\section{Heritability of yield, yield components and growth traits}

The estimates of narrow sense heritability for annual mean rubber yield, summer yield, girth and branching height based on parent-offspring regression is given in Table 1. Results of variance analysis of the clonal population and estimates of broad sense heritability for yield, yield components, growth and anatomical traits are presented in Tables 3, 4 and 5 .

The heritability for annual mean rubber yield based on parent-offspring regression was moderate $\left(h^{2}=34 \%\right.$ in offspring-midparent grouping) to high $\left(h^{2}=56 \%\right.$ in offspring-male parent grouping) (Table 1). Regarding summer yield also, the offspring-male parent grouping showed comparatively high heritability $\left(h^{2}=52 \%\right)$ than the offspring-midparent grouping $\left(h^{2}=36 \%\right)$, based on regression analysis. Heritability for girth was low ( $h^{2}=17 \%$ in offspring-mid parent analysis) to moderate ( $h^{2}=36 \%$ in offspring-male parent grouping) using

Table 3. - Range (R), variance (V), genotypic (G.C.V.) and phenotypic (P.C.V.) coefficients of variation, broad sense heritability $\left(H^{2}\right)$, and genetic advance $(R \%$; percentage of mean) for yield in forty clones.

\begin{tabular}{lrrrrrr}
\hline \multicolumn{1}{c}{ Traits } & \multicolumn{1}{c}{$\mathrm{R}$} & $\mathrm{V}$ & G.C.V. & P.C.V. & $H^{2} \%$ & $R \%$ \\
\hline RY (annual) $\mathrm{g} \mathrm{t}^{-1} \mathrm{t}^{-1}$ & $22.4-77.0$ & $3.71^{* *}$ & 26.2 & 38.1 & 47.5 & 37.2 \\
RY (stress) $\mathrm{g} \mathrm{t}^{-1} \mathrm{t}^{-1}$ & $12.3-60.8$ & $3.32^{* *}$ & 30.5 & 46.1 & 43.6 & 41.5 \\
RY (peak) $\mathrm{g} \mathrm{t}^{-1} \mathrm{t}^{-1}$ & $34.1-95.6$ & $3.70^{* *}$ & 24.4 & 35.4 & 47.3 & 34.5 \\
SD (stress) \% & $13.8-49.4$ & $2.21^{* *}$ & 21.2 & 39.5 & 28.8 & 23.5 \\
LV (annual) $\mathrm{mlt}^{-1} \mathrm{t}^{-1}$ & $77.3-212.4$ & $2.73^{* *}$ & 20.8 & 34.4 & 36.6 & 25.9 \\
LV (stress) $\mathrm{mlt}^{-1} \mathrm{t}^{-1}$ & $31.9-166.6$ & $2.96^{* *}$ & 31.8 & 50.5 & 39.5 & 41.1 \\
LV (peak) $\mathrm{mlt}^{-1} \mathrm{t}^{-1}$ & $121.0-279.8$ & $2.43^{* *}$ & 17.8 & 31.3 & 32.3 & 20.8 \\
\hline
\end{tabular}

RY - Rubber yield; SD - Summer depression; LV - Latex volume; ** significant at $\mathrm{P}=0.01$. 
Table 4. - Range (R), variance (V), genotypic (G.C.V.) and phenotypic (P.C.V.) coefficients of variation, broad sense heritability $\left(H^{2}\right)$, and genetic advance $(R \%)$ for yield components in forty clones.

\begin{tabular}{lrrrrrr}
\hline \multicolumn{1}{c}{ Traits } & \multicolumn{1}{c}{$\mathrm{R}$} & $\mathrm{V}$ & G.C.V. & P.C.V. & $H^{2 \%}$ & \multicolumn{1}{c}{$R$} \\
\hline DRC (annual) & $28.0-40.9$ & $7.32^{* *}$ & 8.5 & 10.3 & 67.8 & 14.4 \\
DRC (stress) & $29.9-43.4$ & $4.15^{* *}$ & 8.2 & 11.5 & 51.2 & 12.1 \\
DRC (peak) & $28.4-40.4$ & $4.04^{* *}$ & 8.4 & 11.8 & 50.3 & 12.3 \\
LFR (annual) $\mathrm{ml} \mathrm{min}^{-1}$ & $2.6-6.4$ & $4.06^{* *}$ & 22.3 & 31.4 & 50.5 & 32.7 \\
LFR (stress) $\mathrm{ml} \mathrm{min}^{-1}$ & $2.2-6.4$ & $3.14^{* *}$ & 22.5 & 34.8 & 41.6 & 29.8 \\
LFR (peak) ml min-1 & $2.9-8.3$ & $4.09^{* *}$ & 22.6 & 31.7 & 50.6 & 33.2 \\
PI (annual) & $2.9-7.3$ & $3.22^{* *}$ & 17.7 & 27.2 & 42.6 & 23.8 \\
PI (stress) & $4.1-11.7$ & $3.25^{* *}$ & 24.0 & 36.6 & 42.9 & 32.3 \\
PI (peak) & $2.1-4.2$ & $1.98^{* *}$ & 11.8 & 23.8 & 24.7 & 12.1 \\
\hline
\end{tabular}

DRC - Dry rubber content; LFR - Latex flow rate; PI - Plugging Index.

*** significant at $\mathrm{P}=0.01$.

Table 5. - Range (R), variance (V), genotypic (G.C.V.) and phenotypic (P.C.V.) coefficients of variation, broad sense heritability $\left(H^{2}\right)$, and genetic advance $(R \%)$ for yield components in forty clones.

\begin{tabular}{lrrrrrr}
\hline Traits & \multicolumn{1}{c}{ R } & \multicolumn{1}{c}{ V } & G.C.V. & P.C.V. & $H^{2} \%$ & $R \%$ \\
\hline Girth (cm) & $60.1-96.3$ & $3.94^{* *}$ & 9.0 & 12.8 & 49.5 & 13.0 \\
Gl (cm yr-1) & $2.3-6.0$ & $2.41^{* *}$ & 18.0 & 31.8 & 31.9 & 20.9 \\
TPL (cm) & $36.8-56.9$ & $2.11^{* *}$ & 7.0 & 13.5 & 27.1 & 7.5 \\
BT (mm) & $5.8-9.3$ & $2.96^{* *}$ & 10.0 & 15.8 & 39.5 & 12.9 \\
TCC (mg g ${ }^{-1}$ of fresh wt.) & $2.1-4.6$ & $1.84^{*}$ & 10.9 & 23.3 & 21.9 & 10.5 \\
Chlorophyll a:b ratio & $0.9-2.1$ & 1.15 & 9.2 & 42.3 & 4.9 & 4.2 \\
\hline
\end{tabular}

GI - Girth increment; TPL - Tapping panel length; BT - Bark thickness; TCC - Total chlorophyll content; $\mathrm{CR}$ - chlorophyll ratio.

* significant at $\mathrm{P}=0.02 ; * *$ significant at $\mathrm{P}=0.01$.

regression. Regarding branching height, offspring-male parent grouping showed a low heritability $\left(h^{2}=18 \%\right)$ in regression analysis. In general, the heritability estimates substantially increased on male parent-offspring grouping (Table 1). Similar variable estimates were obtained using different parent-offspring groupings in western white pine (STEINHOFF and HoFF, 1971) and such inconsistency was attributed to inadequate crossings.

The study showed considerable variation for the rubber yield and its component traits in the clonal population (Tables 3 to 5). Rubber yield in the clonal population exhibited significant variation (range, 22.4 to 77.0 $\mathrm{gt}^{-1} \mathrm{t}^{-1}$; Table 3) suggesting good scope for improvement. Among the yield component traits, latex volume (LV) showed highly significant variation (Tables 3 to 5). However, total chlorophyll content (TCC) and chlorophyll a:b ratio showed comparatively less variation (Table 5). With reference to growth traits, girth showed significant variation (Table 5).

The genotypic coefficient of variation (G.C.V.) ranged from 7.0 for the length of tapping panel to 31.8 for latex volume under stress (Tables 3 to 5 ). The phenotypic coefficient of variation (P.C.V.) ranged from 10.3 for annual mean dry rubber content (DRC) to 50.5 for latex volume under stress (Tables 3 to 5). In general, G.C.V. estimates were lesser than the corresponding P.C.V. estimates indicating influence of environmental factors on the expression of these traits. The low estimates of G.C.V. and P.C.V. for DRC, girth and bark thickness and high estimates for rubber yield and latex volume observed in the present study corroborates earlier finding (ALIKA and ONOKPISE, 1982).

Regarding broad sense heritability of forty clonal genotypes, annual mean rubber yield $\left(H^{2}=48 \%\right)$, rubber yield during peak period $\left(H^{2}=47 \%\right)$ and rubber yield during stress (or summer yield) $\left(H^{2}=44 \%\right)$ showed high estimates of broad sense heritability (Table 3). Among the other yield components, except volume of latex during stress period $\left(H^{2}=40 \%\right)$, remaining yield components showed moderate estimates for heritability $\left(H^{2}=29-37 \%\right)$. Dry rubber content (DRC) based on annual mean showed very high heritability $\left(H^{2}=68 \%\right)$, followed by DRC during stress $\left(H^{2}=51 \%\right)$ and peak $\left(H^{2}=50 \%\right.$ ) periods (Table 4$)$. Latex flow rate based on annual mean and peak period data showed high heritability $\left(H^{2}=51 \%\right)$ followed by latex flow rate during stress period $\left(H^{2}=42 \%\right)$. Plugging indices of annual and stress period showed high heritability $\left(H^{2}=43 \%\right)$ than that of peak period (25\%). Regarding growth traits, girth showed high heritability $\left(H^{2}=50 \%\right)$ than girth increment $\left(H^{2}=32 \%\right)$ (Table 5). While bark thickness showed high heritability $\left(H^{2}=40 \%\right)$ length of tapping panel showed moderate heritability $\left(H^{2}=27 \%\right)$. Total chlorophyll content exhibited moderate heritability $\left(H^{2}=22 \%\right)$ compared to low estimate for chlorophyll pigment ratio $\left(H^{2}=5 \%\right)$.

The estimates of heritability for yield derived from data on two different types of populations were compared with the earlier estimates reported for 
$H$. brasiliensis. Although parent-offspring regression method has not so far been used for estimation of heritability in $H$. brasiliensis, the above estimates corroborate those obtained earlier for yield at different tapping years $\left(h^{2}, 5^{\text {th }} \mathrm{yr}=56 \% ; h^{2}, 15^{\text {th }} \mathrm{yr}=48 \%\right)$ as reported by NGA and SUBRAMANIAM (1974). In contrast, TAN et al. (1975) reported low heritability estimates for average yield over five years $\left(h^{2}=11-14 \%\right)$. Following variance analysis of forty clonal genotypes, high broad sense heritability $\left(H^{2}>40 \%\right)$ was estimated for yield, D.R.C. and latex flow rate. Earlier heritability estimates for annual mean rubber yield in clonal populations ranged from $2 \%$ (ALIKA and ONOKPISE, 1982) to 87\% (GONCALVES et al., 2004). Regarding summer yield, LICY et al. (1992) reported a high estimate $(H=59 \%)$ in $4.5 \mathrm{yr}$ old hybrid clones. As also opined by SImmonds (1989) rubber yield in general is a highly heritable trait.

Regarding girth, the parent-offspring analysis showed moderate to high narrow sense heritability which is comparable with earlier estimates (TAN et al., 1975; TAN, 1979). However, GoncALVEs et al. (2004) estimated very high heritability for girth $\left(h^{2}=71-93 \%\right)$. In the present study using clonal population, girth, annual mean plugging index and plugging index under stress recorded high heritability $\left(H^{2}\right)$. Hitherto, various studies have reported wide range $(9-56 \%)$ of heritability $\left(H^{2}\right)$ estimates for girth. However, few studies have also reported non-significant heritability $\left(H^{2}\right)$ estimates for girth (ALIKA and ONOKPISE, 1982; ALIKA, 1985).

Among other economic traits in the clonal population, bark thickness showed high heritability $\left(H^{2}\right)$ which is comparable to the estimate obtained for $4.5 \mathrm{yr}$ old trees (LICY et al., 1992). With reference to chlorophyll pigment traits, total chlorophyll content showed moderate heritability $\left(H^{2}\right)$ compared to chlorophyll pigmentation ratio.

Table 6. - Genetic correlation $\left(r_{A}\right)$ of yield and growth traits in $H$. brasiliensis based on offspring-parent 'cross-variance' estimates and indirect selection efficiency (parenthesis).

\begin{tabular}{lccc}
\hline & SY & Girth & Branching height \\
\hline ARY* & $0.8557(0.88)$ & $0.8432(0.59)$ & -0.1709 \\
SY** & & 1.3448 & -1.3714 \\
Girth & & & 0.1464 \\
\hline
\end{tabular}

* ARY - Annual Mean Rubber Yield; ** SY - Summer Yield.

\section{Correlations, genetic gain and efficiency of indirect selection}

The estimates of genetic and phenotypic correlations are given in Tables 6 and 7 respectively. Based on parent-offspring cross-variances, annual mean rubber yield showed high genetic correlation with summer yield and girth. Summer yield showed very high correlation with girth and branching height $\left(r_{G}> \pm 1\right)$. Inadequate sample sizes may possibly cause such exaggerated estimates which have been reported earlier (TAN et al., 1975). Annual mean rubber yield and summer yield were negatively correlated with branching height. Using fullsibs, TAN et al. (1975) observed moderate positive correlation between annual mean rubber yield and girth $\left(r_{G}=0.41-0.62\right)$. LIU et al. (1980) estimated high genetic correlation $\left(r_{G} \geq 0.70\right)$ among girth and relative yield.

Regarding correlations among the forty clonal genotypes, annual mean rubber yield exhibited significant positive phenotypic correlation with latex volume, latex flow rate, DRC and bark thickness. Annual mean rubber yield also showed highly significant negative phenotypic correlation with yield depression under stress and plugging index. Since bark thickness shows strong and positive phenotypic correlation, this trait has potential use in future selection as also been suggested by earlier studies (TAN et al., 1975). The correlations obtained in this study are comparable to the earlier reports (MILFORD et al., 1969; PAARDEKOOPER and SAMOSORN, 1969; SETHURAJ, 1981).

The latex yield of a tree from a single tapping is determined by the initial flow rate and the duration of the flow of the latex. Latex flow rate depends upon the bark anatomy characteristics viz. number of latex vessel rings, diameter of latex vessels and other structural characteristics of the laticiferous system of a clone and are genetically determined. Also, yield is correlated with most of the anatomical characteristics of bark (NARAYANAN et al., 1973). A recent study in a 19-year-old clonal population (nine clones of Malaysian origin and three clones of Thailand origin) located at Kottayam (Kerala, India) showed strong correlation coefficients for girth, latex vessel frequency and yield (CHITRA, 2008).

Combining high heritability along with high genetic advance would be more useful in prediction of selection (JoHNSON et al., 1955). In the present study, rubber

Table 7. - Phenotypic correlations among rubber yield and its components.

\begin{tabular}{lrrrrrrrr}
\hline & \multicolumn{1}{c}{ RY } & \multicolumn{1}{c}{ SD \% } & \multicolumn{1}{c}{ LV } & DRC & LFR & PI & Girth & BT \\
\hline SD \% & $-0.38^{* *}$ & & & & & & & \\
LV & $0.96^{* *}$ & $-0.41^{* *}$ & & & & & & \\
DRC & $0.46^{* *}$ & -0.11 & $0.32^{* *}$ & & & & & \\
LFR & $0.87^{* *}$ & $-0.35^{* *}$ & $0.84^{* *}$ & $0.48^{* *}$ & & & & \\
PI & $-0.49^{* *}$ & $0.45^{* *}$ & $-0.57^{* *}$ & 0.14 & -0.17 & & & \\
Girth & $0.59^{* *}$ & $-0.30^{* *}$ & $0.62^{* *}$ & $0.22^{* *}$ & $0.57^{* *}$ & $-0.32^{* *}$ & & \\
BT & $0.53^{* *}$ & -0.22 & $0.53^{* *}$ & $0.36^{* *}$ & $0.49^{* *}$ & $-0.23^{* *}$ & 0.50 & \\
TCC & -0.02 & -0.01 & -1.04 & 0.13 & -0.03 & 0.04 & -0.05 & $0.19^{*}$ \\
\hline
\end{tabular}

RY - Rubber yield; SD - Summer depression; LV - Latex volume; DRC - Dry rubber content; LFR-Latex flow rate; GI - Girth increment; BT - Bark thickness; TCC - Total chlorophyll content.

* significant at $\mathrm{P}=0.05 ; * *$ significant at $\mathrm{P}=0.01$. 
yield, volume and rate of flow of latex over the three periods, yield depression under stress, girth increment, annual mean plugging index and plugging index under stress showed high estimates of genetic advance (Tables 3 to 5 ). Moderate to high heritability coupled with high genetic advance for the above traits imply scope for improvement of these traits through selection. In contrast, low estimates of heritability and genetic advance for traits like chlorophyll content indicated influence of environmental factors in their expression and hence, these traits may not respond well to selection. Similarly, girth, bark thickness and dry rubber content during the three periods showed moderate to high estimates of heritability. However, these traits exhibited low estimates for genetic advance. Hence, these traits may not be suitable for improvement through selection.

Though two clones may have the same yield potential, preference is given to the clone which gives its yield in the shortest period of tapping (PAARDEKOOPER and SAMOSORN, 1969). Plugging index is a measure of the extent of plugging of the latex vessels near their open ends which results in decrease in latex flow rate soon after tapping. In general, trees with long latex flow time have a low plugging index and vice versa and clones with low plugging index reportedly gave higher yields (MILFORD et al., 1969; PAARDEKOOPER and SAMOSORN, 1969). In the present study, rubber yield, latex flow rate and plugging index under stress showed high estimates of expected genetic advance. Hence, it is possible to achieve substantial gains in these traits through selection and breeding. Nevertheless, low plugging index possibly leads to undesirable characteristics like poor girthing rate and high susceptibility to wind damage and drought, and hence, it is may be desirable to select and breed for high yielding clones which also have reasonably high plugging indices (Ho, 1976).

A comparison of genetic parameters for rubber yield and its physiological components showed that rubber yield, latex volume and plugging index during the stress period had high heritability coupled with high genetic advance (Tables 3 to 5). This would indicate the need for selection for these physiological components during stress period than the peak period in order to realize appreciable improvement of rubber yield in the clones.

In order to identify potential component trait for indirect selection for yield, indirect efficiency $\left(C R_{x} / R_{x}\right)$ was estimated based on genetic correlation and heritability. The above estimation assumed identical selection intensity for yield and its components. In the present study using full-sib population, the estimated ratio for indirect selection efficiency was less than optimal (Table 6). Hence, indirect selection for yield using girth and summer yield may not be as advantageous as direct selection.

\section{Conclusion}

The consistent and high estimates of heritability for yield, related yield components and growth traits obtained using two different populations indicated that considerable genetic gain could be realized for these traits. The genetic as well as phenotypic correlation esti- mates of important yield, yield components and growth traits observed in this study suggest that improvement or selection of one trait can possibly result in correlated improvement in the other. For example, selection and breeding for improved yield would possibly lead to indirect improvement in summer yield or girth. Indirect selection using component traits like girth or bark thickness may not be effective for improving rubber yield since the above traits possessed low heritability and genetic correlation. Since rubber yield, latex volume and plugging index during the stress period had high heritability coupled with high genetic advance, it would be more appropriate to conduct selection for the above physiological components of yield during stress period rather than the peak period in order to realize substantial improvement of rubber yield in the clones.

\section{Acknowledgements}

Thanks are due to Mr. ANEESH, P., Statistical Inspector, Rubber Research Institute of India, India, for assistance in statistical analysis.

\section{References}

AlikA, J. E. (1985): Heritability and genotypic gain from selection in rubber (Hevea brasiliensis). Silvae Genet. 34: 1-4.

AliKA, J. E. and O. U. ONOKPISE (1982): Estimation of heritability parameter for yield, girth and bark thickness in rubber (Hevea brasiliensis) from a single pair mating (S.P.M.) design. J. Plant. Crops 10: 102-108.

ARNON, D. I. (1949): Copper enzymes in isolated chloroplasts and polyphenol oxidase in Beta vulgaris. Plant Physiol. 24: 1.

BuRTON, G. W. and E. H. DE VANE (1953): Estimating heritability in tall fescus from replicated clonal material. Agric. J. 45: 478-481.

CHITRA, M. (2008): Genetic variability and associations for yield and yield components in certain exotic clones of Hevea brasiliensis. MSc dissertation, Centre for Plantation Development Studies, University of Calicut, Kerala, India, $63 \mathrm{p}$.

FALCONER, D. S. and F. C. MACKAY (1996): Introduction to Quantitative Genetics. Longman, London, 464 p.

GILBERT, N. E. (1973): Biometrical interpretation. Clarendon Press, Oxford, 125 p.

Goncalves, P de S, A. L. M. Martins, R. B. Da Costa, M de A Silva, A. B. B. CARdinal and L. R. L. GouvÊA (2004): Estimates of annual genetic parameters and expected gains in the second cycle of Hevea genotype selection. Crop Breed. Appl. Biotechnol. 4: 416-421.

Ho, C. Y. (1976): Clonal characters determining the yield of Hevea brasiliensis, pp. 27-44. In: Proceedings of the International Rubber Conference, Kuala Lumpur.

Johnson, H. W., H. F. Robonson and R. E. Comstock (1955): Estimates of genetic and environmental variability in soybean. Agron. J. 47: 314-318.

KempthoRne, O. (1957): An Introduction to Genetic Statistics. Wiley, New York.

Licy, J., A. O. N. Panikkar, D. Premakumari, Y. Annamma VARGHESE and M. A. NAZEER (1992): Genetic parameters and heterosis in Hevea brasiliensis. 1. Hybrid clones of RRII 105 x RRIC 100. J. Nat. Rubber Res. 5: 51-56. 
LIU, N., F. XING, O. U. Jinhan and Z. ShiJIE (1980): A preliminary study on quantitative inheritance of Hevea brasiliensis. I. (a): Estimates of broad sense heritability and genetic correlation of some clones. Chin. J. Trop. Crops 1: 32-41.

Milford, G. F. J., E. C. PAardekooper and C. Y. Ho (1969): Latex vessel plugging, its importance to yield and clonal behaviour. J. Rubber Res. Inst. Malays. 21: 274-282.

Narayanan, R., J. B. Gomez and K. T. Chen (1973): Some structural factors affecting the productibitiy of Hevea brasiliensis. II. Correlation studies between structural factors and yield. J. Rubber Res. Inst. Malays. 23: 285-297.

NGa, B. H. and S. Subramaniam (1974): Variation in Hevea brasiliensis. I. Yield and girth data of the 1937 hand pollinated seedlings. J. Rubber Res. Inst. Malays. 24: $69-74$

PAARDEKooper, E. C. and SANit SAmosorn (1969): Clonal variation in latex flow pattern. J. Rubber Res. Inst. Malays. 21: 264-273.

SethuraJ, M. R. (1981): Yield components in Hevea brasiliensis. Theoretical considerations. Plant, Cell Environ. 4: 81-83.
Simmonds, N. W. (1979): Principles of Crop Improvement. Longman, London, $408 \mathrm{p}$.

Simmonds, N. W. (1989): Rubber breeding, pp. 85-124. In: Rubber, edited by C. C. WeBster and W. J. BAULKWILL, Longman Scientific and Technical, U.S.A.

STEINHOFF, R. J. and R. J. HoFF (1971): Estimates of heritability of height growth in western white pine based on parent-progeny relationships. Silvae Genet. 20: $141-143$.

TAN, H. (1987): Strategies in rubber tree breeding, pp 28-63. In: Improving Vegetatively Propagated Crops, edited by A. J. АввотT and R. K. AtKin, Academic Press, London.

TAN, H., T. K. MukherJeE and S. Subramaniam (1975): Estimates of genetic parameters of certain characters in Hevea brasiliensis. Theor. Appl. Genet. 46: 181-190.

TAN, H. (1979): Heritabilities of six biometrical characters of single pair mating families in Hevea brasiliensis. J. Rubber Res. Inst. Malays. 27: 127-131.

ZoBel, B. and J. TALBERT (1984): Applied Forest Tree Improvement. Wiley, New York.

\title{
A combination of fruit and leaf morphology enables taxonomic classification of the complex $Q$. robur $L_{0}-Q$. $x$ rosacea Bechst. - Q. petraea (Matt.) Liebl. in autochthonous stands in Flanders
}

\author{
By Kristine Vander Mijnsbrugge ${ }^{1), 4)}$, Luc De Cleene $^{2)}$ and Hans Beeckman ${ }^{3)}$
}

(Received 27 July 2010)

\begin{abstract}
Hybrids between Quercus robur and $Q$. petraea have been a sought topic of many studies in Europe during the last decades. Here, leaf and fruit morphology were studied in five oak stands where both species occur naturally intermixed. The stands are relicts of old, possibly medieval coppice wood. Twenty two leaf characters and nine fruit characters were assessed on three leaves and three fruits per tree and for thirty trees per stand. A principal component analysis (PCA) resulted in a bimodal distribution with restricted overlap along the first component when both leaf and fruit data were

1) Research Institute for Nature and Forest, Gaverstraat 4, 9500 Geraardsbergen, Belgium.

2) University College KaHo Sint-Lieven, Association KULeuven, Hospitaalstraat 23, 9100 Sint-Niklaas, Belgium.

${ }^{3}$ ) Royal Museum for Central Africa, Leuvense steenweg 13, 3080 Tervuren, Belgium

4) Corresponding Author: Kristine VAnder Misnsbrugge. Tel. +32 544371 46, Fax +32 54436160 .

E-Mail: kristine.vandermijnsbrugge@inbo.be
\end{abstract}

processed together. For leaf and fruit data separately, the analysis produced only continuous clusters of trees. Two types of putative hybrids can be defined that either show a petiole length of the leaf (PL) according to $Q$. robur and a petiole length of the fruit (FP1) according to $Q$. petraea, or vice versa. These hybrids cluster within both groups of the PCA analysis, but not all are situated close to or in the intermediate area between the groups. A lowered mean relative number of developed acorns in the hybrid groups in comparison to their putative maternal parent, based on the assumption of matroclinal inheritance of PL, is observed. This might indicate a reduced ability for successful fertilisation in the hybrids. These results suggest the presence of putative hybrids and introgressed forms within the morphological distinct $Q$. robur and $Q$. petraea groups and argument for a taxonomically defined $Q$. $x$ rosacea based on PL and FP1 limits.

Key words: Quercus robur, Q. petraea, Q. x rosacea, hybridisation, leaf and fruit morphology, number of undeveloped acorns, taxonomy. 